\title{
Path Analysis on the Associations between Infertility, Stress, and Depression among Women in Surakarta, Central Java
}

\author{
Yesi Retiyansa ${ }^{1}$, Dono Indarto²), Bhisma Murti' ${ }^{1)}$ \\ ${ }^{1)}$ Masters Program in Public Health, Universitas Sebelas Maret \\ 2)Department of Physiology, Faculty of Medicine, Universitas Sebelas Maret
}

\begin{abstract}
Background: In patriarchal societies like Indonesia, infertility is culturally considered as a problem of women. Most of the burden of infertility is borne by women because of a rapid decline in fertility with age, societal pressure and stigma. Infertility can affect psychological disorders such as stress and depression. This study aimed to examine the associations between infertility, stress, and depression among women in Surakarta, Central Java.

Subjects and Method: This was an analytic observational study with a cross sectional design. It was conducted in Surakarta, Central Java, from September to October 2018. A sample of 200 women of reproductive age was selected by fixed exposure sampling. The dependent variable was depression. The independent variables were social support, coping strategy, self-efficacy, infertility, and stress. Data on infertility was obtained from medical record. The other data were collected by questionnaire. The data were analyzed by path analysis.

Results: The likelihood of depression among women was directly increased by stress $(\mathrm{b}=2.09$; $95 \% \mathrm{CI}=1.31$ to $2.87 ; \mathrm{p}<0.001)$ but decreased by good coping strategy $(\mathrm{b}=-1.57 ; 95 \% \mathrm{CI}=-2.34$ to -o.80; $\mathrm{p}<0.001)$. It was indirectly affected by infertility, self-efficacy, and social support.

Conclusions: Depression is directly increased by stress but decreased by good coping strategy. It is indirectly affected by infertility, self-efficacy, and social support.
\end{abstract}

Keywords: depression, stress, infertility, path analysis, women of reproductive age

\section{Correspondence:}

Yesi Retiyansa. Masters Program in Public Health, Universitas Sebelas Maret, Jl. Ir. Sutami No. 36 A, Surakarta 57126, Central Java. Email:yesi.retiyansa@gmail.com. Mobile: +6281252634625.

\section{BACKGROUND}

Infertility is the inability of a married couple to experience pregnancy after regular sexual intercourse for one year or more without using contraception (Zegers-Hochschild et al., 2017). The prevalence of infertility differs in each country, globally, infertility prevalence is $15 \%$, in developing countries is $>30 \%$, and in developed countries is 17-28\% (Al-asadi and Hussein, 2015).

Infertility occurs in 48.5 million couples of childbearing age globally in 2010 (Ghraib and Khait, 2017, 2015). Infertility occurs in 6.7 million women in America, with prevalence increasing from $8.5 \%$ in reproductive age in 1980 increasing to $11 \%$ in 2010 (Winkelman et al., 2016). According to Mascarenhas et al. (2016), there was an increase in the number of infertility couples in the world, from 42 million couples in 1990 to 48.5 million couples in 2010 who experienced infertility.

In Indonesia, in 2013, the percentage of infertility couples at 15-49 years of childbearing age was $9.67 \%$. Estimates of couples of childbearing age in Indonesia in 2013 were 68 million couples, so there were around 6.5 million couples of childbearing age who experienced infertility (Hestiantoro, 2013). The results of the study at Dr. Moewardi hospital Surakarta has increased the number of patients experiencing infer- 
tility, from 979 patients in 2008 increased to 2,205 patients in 2012 and amounted to 4,055 patients in 2016.

Infertility can be experienced by both men and women. Infertility will cause stress and depression, especially in women who are generally blamed for causing infertility (Al-asadi JN and Hussein ZB, 2015). The incidence of depression can be caused by several factors including stress, infertility, self esteem, coping strategies and social support.

\begin{tabular}{l}
\hline SUBJECTS AND METHOD \\
\hline 1. Study Design \\
This study was an analytic observational \\
study with a cross sectional design. The \\
study was conducted in Surakarta, Central \\
Java, from September to October 2018.
\end{tabular}

\section{Population and Samples}

The source population in this study was all women aged 15-49 years. A sample of 200 study was selected by fixed exposure sampling.

\section{Research Variables}

The dependent variable is depression. The independent variable is social support, coping strategies, self-esteem, infertility and stress.

\section{Operational Definition of Variables}

Depression is a condition that is more than just sad. A person with depression will experience a lack of interest in daily activities, significant loss or weight gain, insomnia or excessive sleep, lack of energy, inability to concentrate, feelings of worthlessness or excessive guilt and recurring thoughts about death or suicide.

Coping Strategy is a method used by someone in dealing with problems faced, including strategies that focus on problems, and focus on emotions.

Stress is a situation where there is a transactional gap between a person's physical or psychological demands and situations and facts that are biologically, psychologically, or socially owned.

Infertility is the inability to get a pregnancy after 12 months or more to have sexual intercourse regularly without using contraception.

Self-Esteem is the way a person gives an assessment of himself, namely appreciation, acceptance and self-respect.

Social support is emotional support, information support and real assistance support obtained from husband, family and friends.

\section{Data Analysis}

Univariate analysis was performed to see the frequency distribution and the percentage of the characteristics of the research subjects. Bivariate analysis was conducted to study the relationship between depression in infertile women and independent variables using the chi square test. Multivariate analysis was performed using path analysis with STATA 13.

\section{Research Ethics}

The research ethics include informed consent, anonymity, confidentiality and ethical clearance. The ethical clearance in this study was conducted at the UNS FK on 27 August 2018. Number: 201 / UN27.6 / KEPK / 2018.

\section{RESULTS \\ 1. Sample characteristics \\ Table 1 showed sample characteristics. Table 1 showed that most of the study subjects (55.5\%) had low income, education $<$ senior high school (45.5\%).}

\section{Path Analysis}

Table 2 showed the results of path analysis. Table 2 showed that depression was directly affected by stress (OR=2.09; CI 95\%=1.31 to $2.87 ; \mathrm{p}<0.001)$ and coping strategy $(\mathrm{OR}=-1.57$; CI $95 \%=-2.34$ to $-0.80 ; \mathrm{p}$ $<0.001)$. Coping strategy was affected by stress $(\mathrm{OR}=-2.37$; CI $95 \%=-3.04$ to -1.70 ; 
Journal of Maternal and Child Health (2019), 4(4): 260-266

https://doi.org/10.26911/thejmch.2019.04.04.05

$\mathrm{p}<0.001)$ and infertile $(\mathrm{OR}=-0.77$; $\mathrm{CI} 95 \%=$ -1.43 to $-0.10 ; \mathrm{p}=0.024)$. Stress was affected by social support (OR=-0.64; CI 95\%=1.24 to $-0.04 ; \mathrm{p}=0.036)$, self-esteem (OR=-

\begin{tabular}{lcc}
\multicolumn{1}{c}{ Table 1. The characteristics of research subjects } \\
\hline \multicolumn{1}{c}{ Characteristics } & Frequency (n) & Percentage (\%) \\
\hline Family Income & & \\
Low (<Rp 2,000,00o) & 111 & 55.5 \\
High ( $\geq$ Rp 2,00o,ooo) & 89 & 44.5 \\
Education & & \\
Primary school & 3 & 1.5 \\
Junior high school & 91 & 45.5 \\
Senior high school & 79 & 39.5 \\
Bachelor degree & 27 & 13.5 \\
Fertility & & \\
Fertile & 100 & 50.0 \\
Infertile & 100 & 50.0 \\
\hline
\end{tabular}

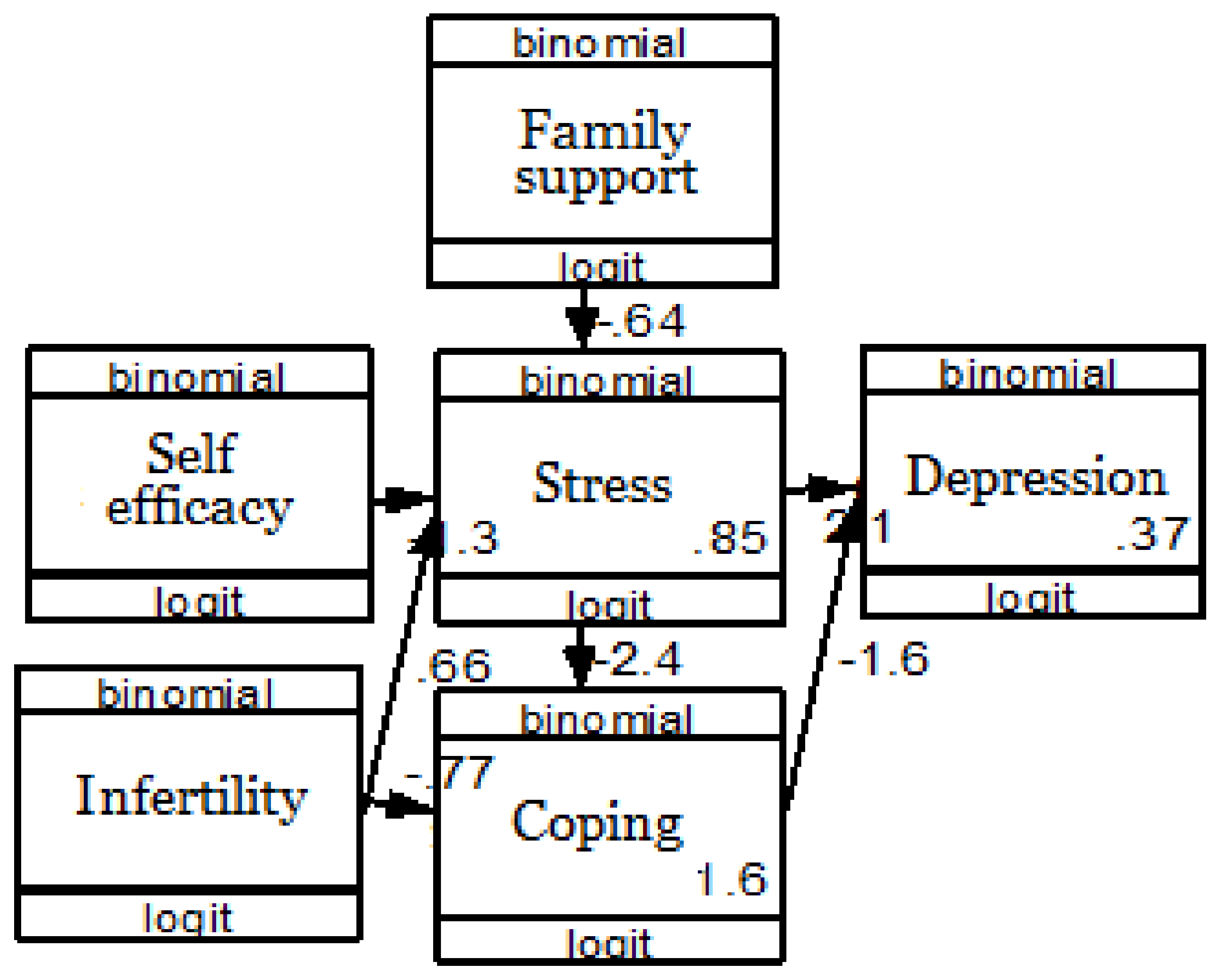

Figure 1. Structural Model of Path Analysis 
Table 2. The Result of Path Analysis

\begin{tabular}{|c|c|c|c|c|c|c|}
\hline \multirow{2}{*}{$\begin{array}{c}\text { Dependent } \\
\text { Variable }\end{array}$} & & \multirow[b]{2}{*}{ Independent Variable } & \multirow[b]{2}{*}{$\mathbf{O R}$} & \multicolumn{2}{|c|}{ CI (95\%) } & \multirow[b]{2}{*}{$\mathbf{p}$} \\
\hline & & & & $\begin{array}{c}\text { Lower } \\
\text { Limit } \\
\end{array}$ & $\begin{array}{l}\text { Upper } \\
\text { Limit }\end{array}$ & \\
\hline \multicolumn{7}{|l|}{ Direct Effect } \\
\hline \multirow[t]{2}{*}{ Depression } & $\leftarrow$ & Stress & 2.09 & 1.31 & 2.87 & $<0.001$ \\
\hline & $\leftarrow$ & Coping Strategy (high) & -1.57 & -2.34 & -0.80 & $<0.001$ \\
\hline \multicolumn{7}{|c|}{ Indirect Effect } \\
\hline Coping & $\leftarrow$ & Stress & -2.37 & -3.04 & -1.70 & $<0.001$ \\
\hline Strategy & $\leftarrow$ & Infertile & -0.77 & -1.43 & -0.10 & 0.024 \\
\hline \multirow[t]{3}{*}{ Stress } & $\leftarrow$ & Social Support (high) & -0.64 & -1.24 & -0.04 & 0.036 \\
\hline & $\leftarrow$ & Self-esteem (high) & -1.34 & -1.97 & -0.71 & $<0.001$ \\
\hline & $\leftarrow$ & Infertile & 0.66 & 0.06 & 1.26 & 0.031 \\
\hline \multicolumn{7}{|c|}{$\mathrm{N}$ Observation $=200$} \\
\hline
\end{tabular}

\section{DISCUSSION}

1. The relationship between stress and depression among infertile women

The result of this study showed that there was a direct relationship between stress and depression among women in reproductive age. High level of stress would increase the depression. This study was in line with a study done by Haimovici et al., (2018). The result of this study indicated that stress has a positive effect on the incidence of depression.

Stress was a psychological symptom experienced by people because of pressure from within themselves and from outside. Stress that continued would lead to depression. Stress and depression were the inhibiting factors for the success of pregnancy programs in infertile women. Milazzo et al. (2016) depression in infertile women affected the failure of Assisted Reproductive Technology (ART).

\section{The relationship between coping strategy and depression among infertile women}

The result of this study showed that there was a direct relationship between coping strategy and depression among women in reproductive age.
Someone would always do coping strategies in overcoming the problems. The expected coping was constructive and positive coping. Effective coping produced permanent adaptation which was a new habit and improvement from an old situation, while ineffective coping ended mal-adaptively, which was behavior that deviated from normative desires and could harm themselves and others or the environment.

A positive coping strategy would reduce the level of depression, this was in accordance with the research conducted (Gojani et al., 2018).

\section{The relationship between stress \\ and depression among infertile women through coping strategy}

The result of this study showed that there was a significant relationship between stress and depression through coping strategy. Depression according to Nevid et al. (2009) was a situation in which a person feel sad, hopeless, depressed, or lose interest in all or various activities for a period of at least 2 weeks. Stress was one of the factors that caused depression (Bakhshayesh, 2012).

The effort made by the individual was called coping. Coping was a process in which someone tried to regulate the differ- 
rences received between desires (demands) and income (resources) that were assessed in an event or a stressful situation. Stress helped us to stay alert. However, high level of stress could exceed our ability to overcome (coping abilities) and caused emotional distress such as depression, anxiety or weakness such as fatigue and headaches (Sarafino \& Smith, 2011)

Gojani et al. (2018) explained that lifestyle changes and stress factors were two of the factors that influenced the occurrence of depression due to a decrease in coping strategies so that stress occurred and would lead to depression in infertile women.

\section{The relationship between infertile and depression through coping strategy}

The result of this study showed that there was a significant relationship between infertile and depression through coping strategy.

Individuals who were able to do adaptive coping would be able to adjust cognitive, emotional and behavioral efforts with the aim of reducing or eliminating unpleasant and stressful conditions beyond the limits of their abilities, as well as emotional tension which caused by these conditions. A woman or housewife who experienced infertility problems was required to have this ability (Komalasari and Septiyanti, 2017).

Ineffective and inadequate coping would make a woman or housewife felt difficult to control stress, which resulted in a reduction in coping that lead to emotional disturbances and depression due to infertility (Taylor, 2015).

\section{The relationship between social support and depression through stress}

The result of this study showed that there was a significant relationship between social support and depression through stress.

Social support provided by a husband, friend, parent or family was one of the factors that determined the difference in individual responses to stress. Social support was also very influential on a person's physical, mental, and cognitive conditions so that depression could occur due to excessive stress (Erdem and Apay, 2013).

Social support was a social resource that can help individuals in dealing with a pressing event, therefore, social support for women during the examination and treatment of infertility was needed especially psychological support because it was a severe stressor (Martins et al., 2013).

\section{The relationship between self-effi- cacy and depression among infer- tile women through stress}

The result of this study showed that there was a significant relationship between selfesteem and depression through stress.

Hill (2013) explained that self-esteem was the way an individual viewed him/ herself, environment, and evaluated his/her perceptions. Self-esteem was included in one aspect of personality that has an important role and has a major influence on individual attitudes and behavior.

Psychological factors such as stress and self-esteem were factors that influence the incidence of depression in infertile women. Women who suffered from infertility desperately need self-esteem or high self-esteem, support from partners, family, friends and the surrounding environment. High self-esteem reduced stress, therefore, it could reduce the depression rate of infertile patients (Cizmeli,et al., 2014).

\section{The relationship between infertile and depression through stress}

The result of this study showed that there was a significant relationship between infertile and depression through stress. 
Women who suffer from infertility would experience stress. Hospital care that did not show results would lead to high stress in women. Stress was very influential on the success of patients who conducted Assisted Reproductive Technology (ART). The high level of stress experienced by infertile women would further reduce the success of pregnancy (Rooney and Domar, 2018).

Infertility was closely related to the incidence of depression. The incidence of depression in infertile women who conduct hospital treatment was $68.9 \%$. Depression was occurred due to loss of identity, feeling of disability, and social stigma (Al-Asadi, et al., 2015). Stress was an intermediate variable in the incidence of depression in infertile women. This was in accordance with the study conducted by Wang et al., (2015).

\section{REFERENCES \\ Al-Asadi JN, Husein ZB.(2015). Depression Among Infertile Women in Basrah, Iraq: Prevalence and Risk Factors. Journal of the Chinese Medical Association, 673-677. \\ Alhassan A, Ziblim AR, Muntaka S (2014). A survey on depression among infer- tile women in Ghana. BMC Women's health.}

Bakhshayesh AZ, Kazeraninejad M, Mongabadi MD, Raghebian M (2012). A comparison of general health and coping strategies in fertile and infertile women in Yazd. Iran $\mathrm{J}$ Reprod Med, 10(6): 601-606.

Cizmeli C, Lobel M, Franasiak J, Pastore LM. (2013). Levels and associations among self-esteem, fertility distress, coping, and reaction to potentially being a genetic carrier in women with diminished ovarian reserve. Fertil Steril, 99(7): 2037-44.
Erdem K, Apay SE (2013). A sectional study: the relationship between perceived social support and depression in Turkish infertile women. International Journal of Fertility and Sterility, 8(3): 303-314.

Gojani GM, Kordi K, Asgharipour N, Esmaeili $H$ (2018). Comparison of the effects of a positive reappraisal coping intervention and problem-solving skills training on depression during the waiting period of the result of intrauterine insemination treatment: A randomized control trial. Int $\mathrm{J}$ Fertil Steril, 12(1): 13-18. doi: 10.22074/ijfs.2018.5155.

Hestiantoro A, Wiweko B, Pratama G, Yusuf D (2013). Konsensus penanganan infertilitas. Jakarta: POGI.

Hidayah N (2007). Indetifikasi dan Pengelolaan sterss infertilitas. Humanitas, 25-33 (4): 1.

Hill VZ (2013). Self Esteem Current Issues in Social Psychology. New York: Psychology Press.

Karaca A, Unsal G (2015). Psychosocial problems and coping strategies among Turkish women with infertility. Asian Nursing Research, 9: 243250.

Kemenkes RI (2015). Profil Kesehatan Indonesia Tahun 2015. Jakarta.

Martins MV, Peterson BD, Almeida V, Mesquita-Guimara J. (2014). Dyadic dynamics of Perceived Social Support in Couples Facing Infertility. Human Reproduction, 29(1): 83-89.

Mascarenhas MN, Flaxman SR, Boerma T, Vanderpoel S, Stevens GA (2012). National, regional, and global trends in infertility prevalence since 1990: A systematic analysis of 277 health surveys. Plos Medicine, 9(12): 1-12. 
Nevid JS, Rathus SA, Greene B (2009). Psikologi abnormal edisi kelima jilid 1. Erlangga: Jakarta.

Sarafino EP, Smith TW (2011). Health psychology. Biopsychosocial Interactions. Seventh Edition. USA: John Wiley \& Sons, Inc.

Septiyanti R, Komalasari G (2017). Koping stres wanita menikah yang belum punya anak. Jurnal Penelitian dan Pengukuran Psikologi, 6(2).

Taylor SE (2015). Health Psychology Ninth Edition. USA: McGraw Hill.

Wang JY, Li YS, Chen JD, Liang WM, Yang TC, Lee YC, Wang CW (2015). Investigating the relationships among stressors, stress level, and mental symp- toms for infertile patients: a structural equation modeling approach. Plos One.

Winkelman WD, Katz PP, Smith JF, Rowen TS (2016). The Sexual Impact of Infertility Among Women Seeking Fertility Care. Sexual Medicine, 4: 190-197.

Zegers-Hochschild F, Adamson GD, Dyer S, Racowsky C, Mouzon JD, Sokol R, Rienzi L, et al. (2017). The international glossary on infertility and fertility care. Fertility and Sterility, 108(3): 393-406. 